\title{
Determination of Amino Acids in Royal Jelly Produced by Honeybees (ApismelliferaL.), Fed on Brewer's Yeast and Yeast Extract Diets Sawsan S. Elmohandes ${ }^{1}$;M. A. I. AbdelAzim ${ }^{1}$; E. W. Zidan' ${ }^{1}$ and Asmaa M. Fawzy ${ }^{1,2}$ ${ }^{1}$ Dept. of Apiculture, Plant Protection Research Institute, Agriculture Research Center, Dokki, Giza, Egypt. \\ ${ }^{2}$ Biology Department, Faculty of Science, Taibah University. Kingdom of Saudi Arabia (KSA).
}

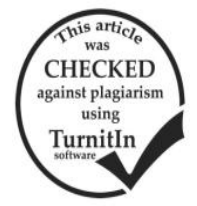

\begin{abstract}
This study were carried out to estimate theartificial supplements effect Prepared with brewer's yeast and yeast extracton amino acid composition of royal jelly (RJ) produced by Carniolianhybridhoneybee colonies. Considering these results, providing supplements for honeybee colonies subjected to royal jelly production can help and strengthen the technological development of the Egyptian beekeeping industry increasing its consumption in the national market. This research presents values analyzed of amino acid composition ofRJa little different from produced honeybee colonies fedon brewer's yeast and yeast extract. While found differences recorded between amino acids Serine $(2.517 \& 2.755 \mathrm{mg} / \mathrm{g}$.), and Threonine $(1.441 \& 1.629 \mathrm{mg} / \mathrm{g}$.) respectively, in RJ all tested samples. This fact shows the important to discuss or change the official method for royal jelly analysis. The characterization of physicochemical parameters is important in order to standardize quality royal jelly produced.
\end{abstract}

Keywords: Honeybees; royal jelly analysis; Amino acids composition; Brewer's yeast; yeast extract.

\section{INTRODUCTION}

Royal jelly (RJ) is a secretion of worker bees, used for feeding bee larvae in the first three days oflife and feeding the queen for its entire life. This substance is reallya RJ product, because itcontained all the chemical compounds that areneedby an organism in order to grow anddevelop, to gain strength and have a long life(Garcia-AmoedoandAlmeida-Muradian, 2007).Honey bees requires proteins (amino acids), carbohydrates (sugars), lipids (fatty acids, sterols), vitamins, minerals (salts), and water, and these nutrients must be in the diet in a definite qualitative and quantitative ratio for optimum nutrition(Standifer,1973).Found different from the honey that produced from flowers nectar or other sugary substances.RJ a solely of glandular secretionproduct; so,its physicochemical compositiondon't affected bythe artificial supplementation givingintact characteristics of the final products (Haydak, 1960).Thus, there is no restriction on thecolonies artificial supplementations. In contrast,Since international beekeepingand Brazilian; products are demandincreasingly, special care is necessary to ensure that final product composition not affectedin use of artificial supplementationthus ensuring both honeybees and customers health of (Brasil, 2007).Due to theRJ high proteincontent, honeybees need a diet rich in sugars, fatty acids,vitamins, minerals, and all essential amino acids from pollen consumption with a small possible addition of honey (Winston, 1987; Schmidt,et al., 1992; Lercker,et al., 1993). Many authors' evaluate effect of artificial supplements and pollen substitute diets to possibility of improving productivity honeybee colonies quantity and quantity (Zidan;Abd ElNaby, 2012;Abd El-Naby;Zidan, 2014; Abd ElWahab,etal., 2016). The recent discovery that RJproteins may have physiological functions as suppressors of allergic reactions, as well as their established anti-hypertensive and proliferation stimulatory proper- ties, opened a new era in application of RJ and honey (Okamoto,etal., 2003).

(Nafea, 2004)fed honeybee colonies on 4 floral honeys and two medicinal plant extracts to produce royal jelly, He found variations between the amino acids compositional royal jelly.(Modifications that affect the protein and amino acid fractions playinga majorrole in RJ commercial quality evaluation during the product shelf life.(Chenand Chen, 1996).

RJ complex composition consists ofamino acids, proteins, organic acids, sugars,sterols, phenols, mineralsand other substance unknown (Viuda-Martoet al., 2008).RJ is one of the richest natural products in aminoacids. Amino acids are very important for humansand animals. RJ contains at least 17 amino acids, including the eight essential ones, andfiveno identified related compounds. The main RJ acid, 10-hydroxy-2decenoic acid is known to havevarious pharmacological effects, includingantibiotic, antitumoral, (Bărnuţiu, et al., 2011).Several authors have studied the chemical composition of RJ, butavailable data is highly variable due to theproductsubstantial variability,different analytical methods and no reference methods for RJ (Wytrychowskiet al., 2013).The aim of this paper is to influence of the medical dried yeast given to honeybee colonies by two-difference way on RJ qualitativeandvariations between total amino acids composition in royal jelly. Inaddition,experiment beekeeping products are advising.

\section{MATERIALS AND METHODS}

present investigation was carried out at Apiculture Department, Plant ProtectionResearchInstitute,Dokki, Giza, during year 2016twelve healthy honeybee colonies from Carniolianhybrid were conducted for this study. These coloniesdivided into two groups, each of about equal strength containing at least eightcombs covered with bees.

Feeding Honeybee Colonies: 
(Group1) fed of each colony A cake of 100gm food supplement consisted of one partbrewer'syeast mixedwith nine parts powder sugar(w/w) according to zidan, 2009.

(Group2)fed of each colony yeast extract adding sugar syrupy at a ratio of 1:9.

Yeast extract was prepared frombrewer'syeast (Saccharomyces cerevisiae), dissolved in water followed by adding sugar at a ratio of 1:1and kept 24 hours in a warm place for reproduction according to the methods of Morsiet al., 2008.

All groups of the tested honeybee colonies were fed for 2 month/ two once weekly consecutively, throughout the experimental periods, from first February until end of March 2016.

The Royal jelly collected from all groups of the tested honeybee colonies into $500 \mathrm{mg}$ capsules to be stored in the freezer at $-20^{\circ} \mathrm{Ctill}$ the study began.

Laboratory analysis:

Determination of Amino acids content.

Separation of Amino acids by GLC:Amino acids were transported to micro reaction vial and derivatization .Procedurewere carried out according toLandault and Guiochen1964, usingNbutanol and trifluoroaceticanhydride. A Varian Model 3700GC equipped with FID, was used. TheSeparationwere accomplished with the following conditions:Column: 39, OV-225 an (Chromosorb-W-HP,80-100 wesh)glass.Program: 4 min. At $80 \mathrm{OC}$ and increased to $200 \mathrm{OC}$ at rate of $4 \mathrm{OC} / \mathrm{min}$. then stable for a min.Inject and detect: Temp. 250OC.Carrier gas (N2, $20 \mathrm{ml} / \mathrm{min}$, H2 $20 \mathrm{ml} / \mathrm{min}$ and air $200 \mathrm{ml} / \mathrm{min}$ ) At ten: $16 \times 10-1$ AMPS.MV.

Reagent:

Iron-Acetic acid solution. A weight of $0.22 \mathrm{~g}$. of $\mathrm{FeCh}-6 \mathrm{H} 2$ in $0.5 \mathrm{ml}$ distilled water and then completed up to one liter with glacial acetic acid.
Accurately $0.5 \mathrm{~g}$ of royal jelly were mixed with $10 \mathrm{ml} \mathrm{HCL}$ at $100 \mathrm{OC}$ overnight, then filtered and the remaining HCL was removed by heating till dryness.

Statistical analysis:

Amino acids contentdata for all analyzed RJsamples to analysis of variance (ANOVA) through SPSS computer program. Means were comparing using Duncan's Multiple Range tests, and defined as $\mathrm{p}<0.05$.

\section{RESULTS AND DISCUSSION}

Although freshly harvested and commercial RJcomposition has been studied extensively (Marghitas et. al., 2010; Pavel et. al., 2014), amino acids content in RJ have received little research ate nation. In the present study, compare between results ofamino acids composition in fresh RJproduced by honeybees fed on brewer's yeast and yeast extractdiets, are present in Table 1. The most abundant amino acids in RJ wereaspartic acid (average 9.67\&10.26 mg/g). There was no significant difference between the content of aspartic acid for both group of tested samples. The next most abundant amino acids were Lucien (average $4.055 \& 4.463 \mathrm{mg} / \mathrm{g}$ ). The lowestamino acids concentration of all groups with Methionine (average 0.597 \& $0.584 \mathrm{mg} / \mathrm{g}$ ) respectively. The data previous according to (Balkanskaand Zhelyazkova, 2015) determined high concentration of freeaspartic acid has the highest concentration and the lowest was with Metof all amino acid found in commercial and fresh RJ.

The concentration of Lysine, Valise, Proline, Glutamic acid, Isoleucine, Glycine, Histidine, Phenylalanine, Tyrosine, Alanineisno significant differences between RJ samples was found for amino acids the limit of recoded ranged to 3.001 - 1.217 $\mathrm{mg} / \mathrm{g}$.brewer's yeast and yeast extract.

Table1. Estimateof amino acids in the royal jelly produced by honeybees (ApismelliferaL.)fed on brewer's yeast and yeast extract diets.

\begin{tabular}{|c|c|c|c|c|c|}
\hline $\begin{array}{l}\text { Treatment } \\
\text { Amino acids (mg/g) }\end{array}$ & Dry yeast & Yeast extract & $\mathbf{F}$ & $P<0.05$ & $\mathbf{L s D}_{0.05}$ \\
\hline Histidine & 1.549 & 1.295 & 1.433 & 0.1059 & $0.342^{\mathrm{ns}}$ \\
\hline Lysine & 2.959 & 3.001 & 0.032 & 0.8662 & $0.62^{\mathrm{ns}}$ \\
\hline Lucien & 4.055 & 4.463 & 3.219 & 0.147 & $0.634^{\mathrm{ns}}$ \\
\hline Isoleucine & 2.004 & 1.977 & 0.106 & 0.761 & $0.227^{\mathrm{ns}}$ \\
\hline Valise & 2.812 & 2.649 & 1.038 & 0.366 & $0.436^{\mathrm{ns}}$ \\
\hline Methionine & 0.597 & 0.584 & 0.143 & 0.725 & $0.122^{\mathrm{ns}}$ \\
\hline Phenylalanine & 1.500 & 1.403 & 1.925 & 0.2375 & $0.206^{\mathrm{ns}}$ \\
\hline Proline & 2.726 & 2.813 & 0.615 & 0.477 & $0.307^{\mathrm{ns}}$ \\
\hline Threonine & $1.441 \mathrm{~b}$ & $1.629 \mathrm{a}$ & 36.41 & 0.008 & $0.102 * *$ \\
\hline Serine & $2.517 \mathrm{~b}$ & $2.755 \mathrm{a}$ & 10.10 & 0.034 & $0.206^{*}$ \\
\hline Tyrosine & 1.420 & 1.357 & 1.176 & 0.3392 & $0.16^{\mathrm{ns}}$ \\
\hline Aspartic acid & 9.67 & 10.26 & 2.04 & 0.228 & $1.17^{\mathrm{ns}}$ \\
\hline Alanine & 1.239 & 1.217 & 0.161 & 0.7086 & $0.16^{\mathrm{ns}}$ \\
\hline Glycine & 2.041 & 1.926 & 1.445 & 0.296 & $0.270^{\mathrm{ns}}$ \\
\hline Glutamic acid & 2.667 & 2.779 & 5.33 & 0.082 & $0.136^{\mathrm{ns}}$ \\
\hline Total AA & 39.197 & 40.108 & - & - & - \\
\hline
\end{tabular}

In our study, significant differences recorded between amino acids Serine $(2.517 \& 2.755 \mathrm{mg} / \mathrm{g}$.), the $\mathrm{F}$ tested were10.10and $(\mathrm{P}<0.05)$. While highest Significant were Threonine $(1.441 \& 1.629 \mathrm{mg} / \mathrm{g}$.), the F tested were $36.41 \mathrm{mg} / \mathrm{g}$. and $(\mathrm{P}<0.05)$, respectively in all $\mathrm{RJ}$ tested samples. Inmind that there are variable factors affected the yeast extract composition solvent in water conduct absorbent profile easy. (Balkanska and Zhelyazkova 2015) reported that honey and pollen are previous of RJ Honeybees forage different plants. Thus, 
honeybee and pollen are always mixture of many sources. Bee pollen and honey amino acids profile canaffect the RJ amino acids composition in some directions. All Bulgarian RJ samples were harvestfromMay to September duringdifferent plants flowering season.

Finally, non-significantproduced from honeybee colonies fed dry yeast and yeastextract, the totals amino acid content of RJ samplesdetermined were $39.197 \& 40.108 \mathrm{mg} / \mathrm{g}$, respectively. (Sereia and Toledo 2013) found thatroyaljellycomposition did not affect by artificial supplementation produced by the different treatments, thus the supplementsprovision to Africanized honeybee colonies viewed to royal jelly production. In addition, the previous authors of literature (Chen and Chen, 1996; Nafea, 2004; Wytrychowskietal.,2013).

\section{CONCLUSION}

As conclusion, the artificial supplementation did not affect the mostroyal jellycomposition produced with the different treatments, and thus the provision of supplements considered as a first approach to characterize RJ based on its amino acid content total amino acids was analyzed.Thus, the provision of supplements to honeybee colonies subjected to royal jelly production can help and strengthen the technological development of the Egyptian beekeeping industry improving its national market.

\section{REFERENCES}

Abd El-Naby, S. M. and Zidan, E.W. (2014): Activity Level of Lactate dehydrogenase and $\beta$ glucosidase Enzymes in the honeybee Colonies, (Apismellifera L.) with Different feedin. Egypt. Acad. J. Biolog. Sci., 6(1):93-100.

Abd El-Wahab, T.E.,Ghania, A.M.M. and Zidan, E.W. (2016):Assessment a new pollen supplement diet for honey bee colonies and their effects on some biological activities,J. of Agric.Techn. Vol. 12(1):55-62.

Balkanska, R. andZhelyazkova, I. (2015): Determination of amino acids and protein content in fresh and commercial royal jelly from bulgaria.,Bull. Chem. Soc. Ethiop. , 29(3), 485-490.

Bărnuţiu, L. I.;Mărghitaş,L. A1.; Dezmirean, D. S.;Mihai, C.M. and Bobis, O. (2011): Chemical Composition and Antimicrobial Activity of Royal Jelly -Review Animal S. and Biotechnologies, 44 (2).

Brasil.Ministério da Agricultura, Pecuária e Abastecimento. Secretaria de Política Agricola (2007): InstitutoInteramericanode CooperaçãoparaaAgricultura. Cadeiaprodutiva de flores e mel. Brasília: IICA, MAPA/SPA, p. 85-134.

Chen C., Chen S. (1996): Changes in UV-VIS spectroscopic spectra and quality stability of RJ under various storage conditions, J. Chin.
Agric.Chem. Soc. (Zhongguo NongyeHuaxueHuizhi) 34, 257-265.

Garcia - Amoedo L.H., Almeida MuradianLigiaBicudo (2007): Phisicochemical composition of pure and adulterated royal jelly, Quim. Nova, Vol. 30, No. 2, $257-259$.

Haydak, M. H. (1960): Vitamin content of royal jelly from honey bee colonies fed normal diet and from those fed pollen substitutes. Annals of the Entomological Society of America, v. 53, n. 5, p. 695 ,

Landault,G. and Guiochen,G. (1964):Separation of amines by gas liquid chromatography tlefonsupport,J. chromatog. 13(2):565-567.

Lercker, G; Caboni, M F; Vecchi, M A; Sabatini, A G; Nanetti, A. (1993): Caratterizzazionedeiprincipalicostituentidellagelatinareale. Apicoltura 8: 27-37.

MarghitasLiviu, Daniel Dezmirean, OtiliaBobiş, VictoritaBonta, Oltica G. Stanciu, IosifGergen, Monica Harmanescu- (2010): The Development of a Biochemical Profile of Acacia Honey by Identifying Biochemical Determinants of its Quality." NotulaeBotanicaeHortiAgrobotanici Cluj-Napoca 38(2): 84-90.

Morsi,M.K.;B. El-Magoli; N.T. Saleh;E.M. El-Hadidy and H.A. Barakat,(2008):Study of antioxidants and anticancer activity licorice Glycyrrhizaglabra extracts. Egyptian J. Nutr. And Feeds,2(33): 177-203.

Nafea,E.A.(2004): The biological effect of honeybee products as environmentallySafe substances against some pathological microorganisms,Ph.D. Thesis, Ain Shams Univ., in Inst., of Environ., Stud., and Res., Egypt, pp.116.

Okamoto I, Taniguchi Y, Kunikata T, Kohno K, Iwaki K, Ikeda M.1. (2003): Major royal jelly protein 3 modulates im-mune responses in vitro and in vivo. Life Sci;73: 2029-45.

Pavel, C.; Marghitas, L.; Dezmirean, D.; Tomos, L.; Bonta, V.; Sapcaliu, A.; Buttstedt, A. (2014): Comparison between local and commercial royal jelly - use of antioxidant activity and 10hydroxy-2-decenoic acid as quality parameterJ. Apic.Res., 53, 116-123.

Schmidt, J. O.; Buchmann, S. L.: GRAHAM, J. M. (1992): The hive and the honeybee in other products of the hive. Hamilton: Dadant and Sons, (Ed.). p. 927-988.

Sereia, M. J. and Toledo, V. A. A., (2013): Quality of royal jelly produced by Africanized honeybees fed a supplemented diet Food Sci. Technol, Campinas, 33(2): 304-309.

Standifer, L. N.; Owens, C. D.; Mills, J. P. and Levin, M. D. (1973): Supplementary feeding of honeybee colonies in Arizona. Am. Bee J. 113: 298-301.

Viuda-Martos, M; Ruiz-Navajas, Y; FernándezLópez, J; Pérez-AlvarezJA.(2008): Functional properties of honey, propolis, and royal jelly. Journal of Food Science, v. 73, n. 9, p. 117-124. 
Winston, M. L. (1987): The biology of the honey bee. Massachusetts: Harvard University Press, 281 p.

Wytrychowski M, Chenavas S, Daniele GI, Casabianca, H.; Batteau, M.; Guibert, S. (2013): Physicochemical characterisation of French royal jelly: comparison with commercial royal jellies and royal jellies produced through artificial bee-feeding. J Food Comp. Anal.;29:126-133.

Zidan, E.W. (2009): Studies on varroa mite and its effect on productivity of honeybee colonies, Ph.D. Thesis, Banha Univ., Fac. of Agric. Moshtohor, Egypt, pp. 210.
Zidan, E.W. and Abd El-Naby, S. M. (2012): Effect of Different feeding on activity of carbohydrate enzymes in the honeybee Colonies, (Apismellifera L.), Egypt. J. Agric. Res., 90(2):469-482.

\section{تقدير الأحمـاض الأمينيـة في الغذاء الملكي المنتجج مسن تغذيـة طوائف نحل العسل بـالخميرة الطبيـة الجافـة والمستخلصه

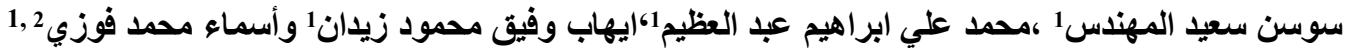

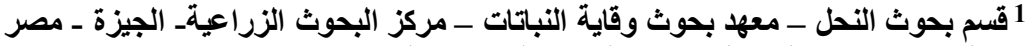

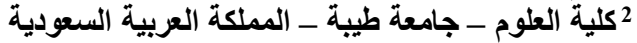 \\ أجريت هذه التجربة لمقارنة تأثير تغذية طو ائف نحل العسل بكل من الخمبرة الجافة ومستخلص الخميرة علي جودة

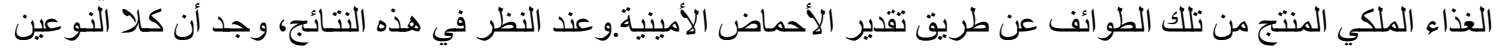

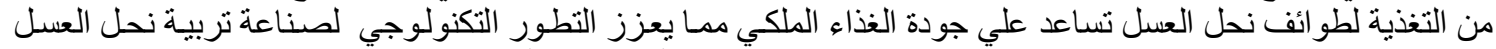

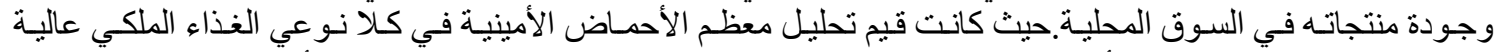

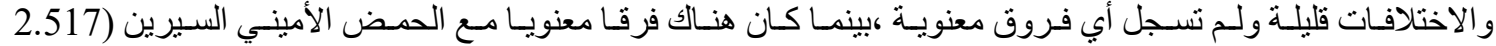

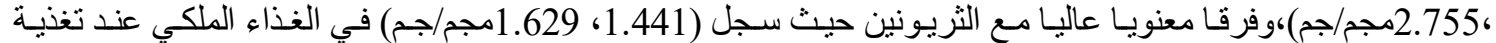

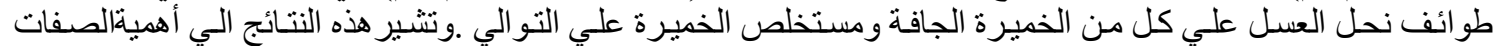 الكيميائية في تحديد جودة المنتج .}

